\title{
"We had a toilet!" The modernisation of the countryside as perceived by the inhabitants, the public spaces and the presence of politics in the new settlements in Italy and colonial Libya (1932-1939).
}

\author{
Vittoria Capresi ${ }^{1,1}$ \\ ${ }^{1}$ Technical University Berlin, Habitat Unit - Chair of International Urbanism and Design
}

\begin{abstract}
The foundation of the new settlements, both in Italy and colonial Libya, was a step to achieving the project of internal colonisation launched by Mussolini. The modernisation of the countryside was promulgated by the Fascist propaganda, which presented only a misleading impression of how life was. What happens if - as an additional level of interpretation - we add the narratives of the inhabitants who lived these moments? This paper presents this original methodical approach, introducing the narratives of the settlers in relation to the presence of politics in daily life during the Fascist era.
\end{abstract}

\section{Introduction}

In the beginning my mother was worried about the desolation of the place. She came from an Alpine valley, scattered with lots of little villages, and she felt isolated. But she was enthusiastic about our house. There was everything we needed, even plates and forks, and beds and mattresses, wheat, rice, oil and matches, much more than we'd ever dreamt of having in Italy. We had three rooms and a kitchen. Outside, besides the courtyard, there was a second building with the stable, the hen-house, the pigsty and a warehouse. And there was even a toilet! ${ }^{2}$

For the settlers' families, their arrival in the new settlements built by the Fascist regime in the Pontine Plain (Italy) and colonial Libya was a crucial moment, an absolute break in their lives as they saw for the first time what was to become their new homeland ${ }^{3}$.

\footnotetext{
${ }^{1}$ Corresponding author: vittoria.capresi@tu-berlin.de

${ }^{2}$ M.G.S. speaks about her family's arrival in Libya "All'inizio mia madre era preoccupata per la desolazione del posto, lei veniva da una valle alpina disseminata di paesini e li si sentiva isolata. Della nostra casa però era entusiasta, c'era tutto quello che serviva, perfino i piatti e le posate, $\mathrm{i}$ letti con i materassi, la farina, il riso, l'olio e i fiammiferi..., più di quanto avesse mai sognato di avere in Italia. Avevamo tre camere e una cucina. Fuori, oltre il cortile, c'era un secondo edificio con la stalla, il pollaio, il porcile e il magazzino. E c'era perfino il gabinetto." [1:34].

${ }^{3}$ The project of internal colonisation involved several other areas in Italy as well as the Pontine Plain - but, due to its position close to Rome, the Pontine Plain project was awarded iconic status by the fascist propaganda. For a more complete list of the settlements and borghi, see [2].
} 
The project of internal colonisation launched by Mussolini was implemented between 1932 and 1939. This envisaged the relocation of population from regions in Italy that were overpopulated and had high unemployment rates, to the newly reclaimed areas ${ }^{4}$. Except for a few cases, the new settlements based their economy on the agricultural use of land, through the agrarian colonisation of previously uncultivated areas $^{5}$. This process was promulgated by the rampant Fascist propaganda of the time as the decisive modernisation of the countryside: historical photos and films and oral and written descriptions offered an unequivocal picture of progress and modernity, presenting only a partial and misleading impression of how things were.

Much scholarly work has been done on the new towns in the Pontine Plain, and also - though not as comprehensive - on the colonial new towns in Libya. The various stages of planning, the reactions of the press at the time, and the discussions around modernity have been extensively explored. In addition, numerous field surveys have produced a comprehensive mapping of the typologies and chronologies of the development $[5,6,7,8]$.

The role of the settler, however, is rarely mentioned in scholarly research: what about the inhabitants?

If we look at the contemporary press, we find two main ways in which architecture and the relation between space and people are represented. The architecture is mostly portrayed as empty, with an emphasis on the static composition of white forms over an almost nude landscape. The architecture historian Giorgio Massaretti argues that the few pictures of the Libyan settlements published at the time were mainly taken using actors [9]. On the other hand, we find pictures celebrating Fascism as a choral event: people working together happily in the fields, acclaiming the Duce, and gathering in the main square for the political festivities. The propaganda machine disseminated an image of perpetual acclamation, the picture of a land united under and in support of Mussolini. Dissent was prohibited, individual stories were ignored and the private sphere was totally absent.

How was the process of resettlement and agrarian reclamation really experienced by the inhabitants? How did they perceive the modernisation of the countryside? What happens if - besides the interpretation of the architecture and as an additional level of understanding - we add the narratives and memories of the inhabitants who lived these moments? What new insights can the analysis of the oral histories of those Fascist spaces offer us?

This paper aims to compare the narratives of the settlers in colonial Libya and in the Pontine Plain, in particular the area of Pontinia, proposing as an additional layer of interpretation the analysis of the very subjective perceptions of the spaces. The main theme presented relates to the presence of politics in the daily life of the settlers.

The idea of comparing these two case studies, similar with regard to the political aims and the organisational processes of colonisation via settlements, has the principal purpose of providing new insights towards greater understanding of the individual sites ${ }^{6}$.

\footnotetext{
${ }^{4}$ Political reasons were also behind the relocation of some families, to isolate them in the countryside. See $[3,4]$.

${ }^{5}$ There are very few examples of new towns based on an industrial economy, see for example Carbonia (Sardinia), Arsia and Pozzo Littorio (today Raša and Podlabin in Croatia).

${ }^{6}$ Both the Pontine Plain and the settlements in colonial Libya are case studies of MODSCAPES - Modernist Reinvention of the Rural Landscape: www.modscapes.eu .
} 


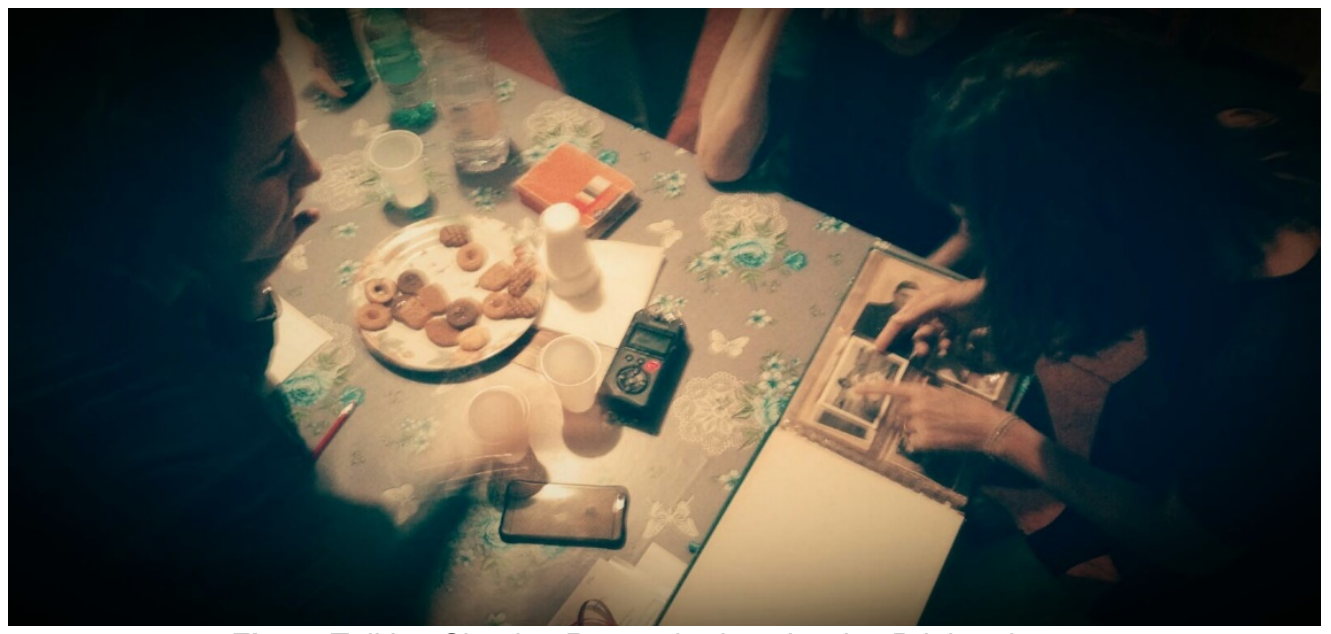

Fig. 1. Talking Chatting Remembering: Jessica Brighenti, 2017.

A session underway. (Source: the author).

\section{A few words about the method}

The research method used is somewhat experimental, combining oral history methods, architectural survey and analysis, so that the narratives are overlapped with research of the urban spaces, of the architecture, and direct documentation of material remains. Through this overlay of different approaches, the scale, sharpness and precision of the architecture is questioned or, more accurately, integrated with multidimensional emotional and private layers, which enrich the overall understanding of what the public and private space of the Fascist new settlements was and is.

The Italian settlers were expelled from Libya in the wake of Gaddafi's coup in 1970, and for the most part returned to their towns of origin or to the big cities in the north that were looking for labourers to drive the industrial boom that was taking place. The narratives collected up until now are from families who lived in various settlements in Libya, and for the most part returned after the coup.

The Pontine Plain settlers were easier to trace, since in most cases the families still live on their original farms.

In the case of both groups, few memoirs have been compiled and published, or even written ${ }^{7}$, and those that do exist are characterised by nostalgia and sentimentalism. This is particularly true of the Libya case studies, where memories are greatly influenced by the fact that the families were obliged to leave. The experience of forced rupture created a myth around the past, reinforced by the difficult conditions many of the returnee families had to face once back in Italy.

In addition to written memoirs, semi-structured interviews were carried out with the families of the original settlers, to explore in more depth the relation with space and politics. These interviews usually took place in the interviewee's home, in the presence of the whole family: my work was considered to be an important event, an opportunity to reconstruct the history of the whole family. The interviews usually took several hours,

${ }^{7}$ Of great help was the AIRL - Associazione Italiani Rimpatriati dalla Libia [Association Italians repatriated from Lybia], which keep in its library several manuscripts by Italians who lived in Libya. I thank the director Giovanna Ortu and the whole team who made these documents available for this research. 
and were followed by an informal chat, poring over photo albums and family heirlooms, and visiting the original settler houses (in the case of Pontinia).

The sample is of course not big enough to generalise objective facts. In the case of Libya, for example, only in one case was I able to carry out multiple interviews related to a single settlement. Originally, there were 28 settlements, but today it is difficult to trace families who originally lived in the same settlement ${ }^{8}$. This, however, should in no way influence this work, which aims mainly at proposing and testing a new approach to the analysis of the Fascist new settlements.

\section{A brief historical background}

Through agrarian colonisation and the promotion of farm work in general Mussolini pushed forward his project of de-urbanisation and ruralisation, which he had made public during his speech at the Camera dei Deputati [Chamber of Deputies] on the $26^{\text {th }}$ of May 1927. Known as the Discorso dell'Ascensione [Ascension Day speech], this speech was where he announced the future government's plan to move people out of the cities and return them to the countryside. The plan was to be put into practice via several projects, like the battle for wheat, promoted in 1927, the law on the Bonifica Integrale passed in 1928 and a number of measures against urbanisation promoted starting from 1939. The propaganda for moving to the countryside was used by the regime to prevent the formation of workers' associations in the cities, and moreover to build a mass consensus through the promise of the reduction of unemployment and poverty, to be achieved through the provision of farm work.

The colonisation of the Agro Pontino, a marsh district south of Rome, took from 1927 to 1939. In addition to the draining of the marshes, it involved the subdivision into agrarian parcels of 840 square kilometres of land, the introduction of around 3000 farms and 18 villages (borghi) and five new settlements: Littoria (1932, today Latina), Sabaudia (1933-34), Pontinia (1935), Aprilia (1936-37), and Pomezia (1938-39) [8: 13].

The programme for agrarian colonisation in Libya started in 1934, when five experimental settlements were introduced in Cyrenaica. The plan for mass colonisation was announced in 1937 and envisaged the transfer of a total of 100,000 small farm workers to the colony, divided into five yearly transfers of 20,000 people. In 1938 and 1939 the first two stages of implementation took place, with the organised transfer of around 40,000 Italian settlers to the coasts of Tripolitania and Cyrenaica. 27 settlements were built on the coastal strip of the colony ${ }^{9}$. In the case of Libya, the administrative level of the borghi did not exist, with individual farms depending directly on the geographically closest settlement.

The urban layout of the settlements was quite similar for all the villages, both in Italy and in the colony ${ }^{10}$ : a piazza or system of piazze was conceived to be the most immediate answer to the need to create an enclosed space as a physical and symbolic core for the settlers. In this sense, the square was fundamental in providing a sense of community and a focal point for the newly born societies.

\footnotetext{
${ }^{8}$ Up until May 2018, I carried out 12 interviews related to Pontinia and 11 related to the Libya case study.

${ }^{9}$ For a detailed study of the new settlements in colonial Libya see [5].

${ }^{10}$ With the exception of the more intellectual town planning experiment of Sabaudia. The climate did not particularly influence the design of the new settlements in Libya, except for the use of arcades and flat roofs. See [5], in particular the description of the D'Annunzio centre.
} 
Both in the Pontine Plain and in Libya the settlements were actually more "logistic centres" than towns, conceived as being the centre of public life: they combined administrative, political, commercial and religious functions, but the settlers did not live there ${ }^{11}$. The settler families were in fact systematically scattered in the surrounding countryside, each in a dwelling provided by the regime on the plot of land they were required to cultivate. Their isolation was intended to reinforce their link with their plot of land and encourage them to devote themselves totally to the land they had to "redeem".

But did this isolation really work out the way the regime had planned? Did settlers visit the settlements, how often, and why? Did they gather in the main square only for political events?

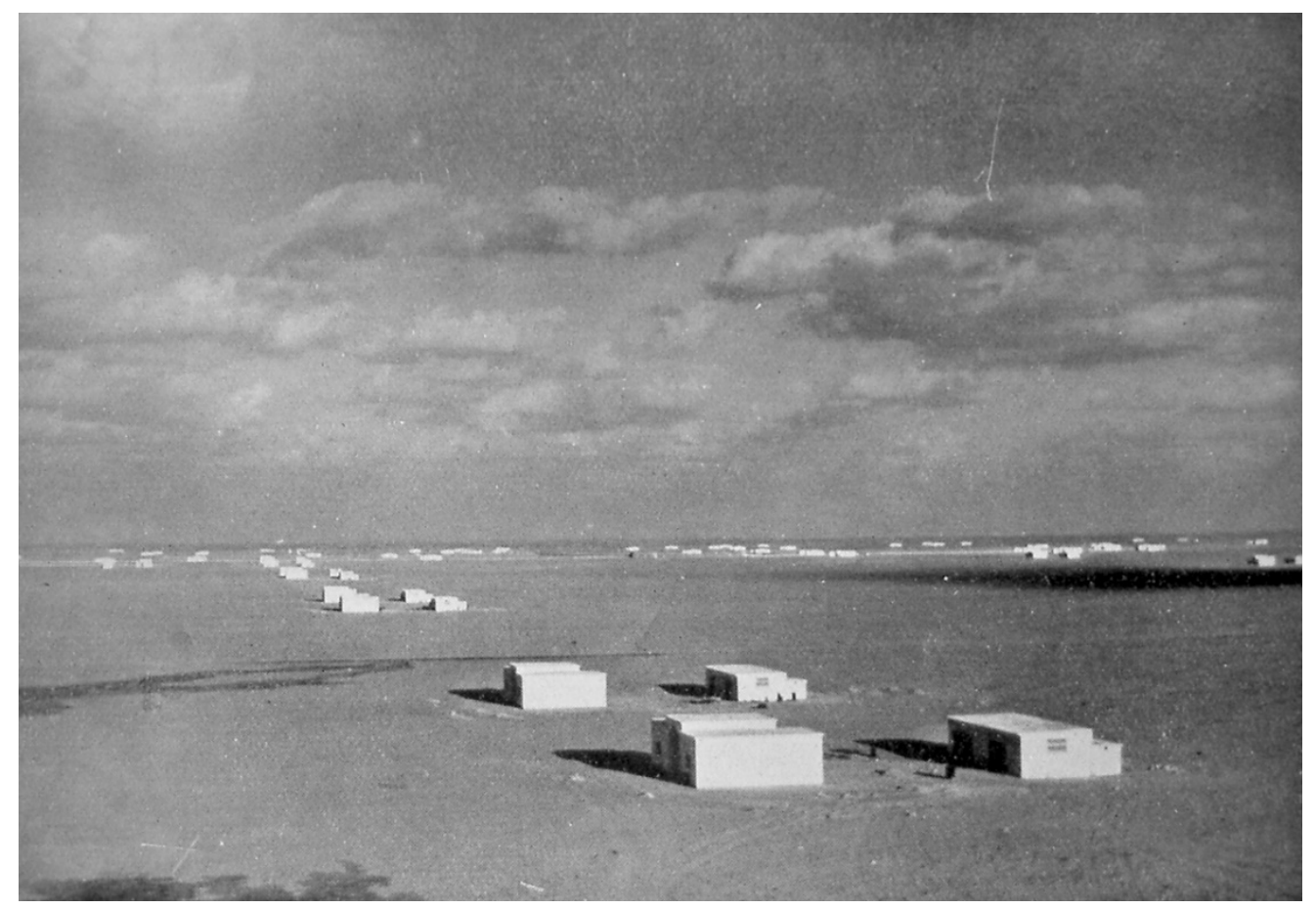

Fig. 2. The dwellings of the settlers in Libya, settlement Crispi, Tripolitania.

Source: Rivista delle colonie (1939), vol. 13: n.p.

\section{Talking, chatting remembering}

\section{The presence of politics in the lives of the settlers}

The architectural typology of the Casa del Fascio was not centrally defined, but in many of the settlements in Libya the House of the Fascist Party is immediately recognisable both because of the balcony, the arengario, which was supposed to be used by members of the Fascist party to address and indoctrinate the people, and because of the key position of the building in the overall design of the square.

${ }^{11}$ For a detailed description of how the politics of building apartment houses in the five new settlements in the Pontine Plain evolved see: [8]. 
Mussolini went to Libya only twice during the colonisation period, and none of the interviewees spoke of Fascist party members speaking from the balcony in the square $^{12}$.

The active presence of Fascism was limited to the so-called weekly 'Fascist Saturday', when young people and men were required to gather together to take part in gymnastic exercises.

Ignazia was born in 1927. Her family, comprised of father, mother and six children, moved from a little town in Sicily to the village of Berta in 1934: they belonged to the very first wave of colonisation. Ignazia remembers how King Vittorio Emanuele once paid a visit to Berta and how the settlement children had to stand in a line waiting for him for many hours. They waited so long, she cannot remember the moment he arrived, or even if he did.

Acquilina recounts that she lived in Giordani, a settlement with no municipal offices, which meant that the inhabitants had to travel to nearby Bianchi, a bigger settlement, for all bureaucratic issues.

In the village Giordani there was no Municipality, it was depending from Bianchi. The seat of the Mayor was there, and probably activities related to Fascism were also organised there.

She also remembers that there was no Fascist party seat in her settlement and that no political meetings were held there. Neither she nor her parents and grandparents ever attended one ${ }^{13}$. In the master plan of Giordani published in Architettura e Arti Decorative magazine in April 1939 (p. 254), there is an indication that the municipality offices, the Fascist party offices and the post office were all accommodated in one building. It is probable that, due to the isolated position of Giordani, on the edge of the Libyan desert, none of the offices were permanently occupied, or perhaps even occupied at all.

The situation was different in the settlements in the Pontine Plain: here the propaganda machine was in full working order and Fascism was intensely present in the daily life of the settlers. Mussolini visited the families many times, making a show of being one of them and working alongside them.

Nelia remembers that one day a delegation informed her family that the Duce would be coming to eat at her house. He arrived at 10 am on the appointed day and went straight to the threshing shed, then joined the family in the kitchen to eat a lunch of bean soup [10: 34].

This was a fantastic piece of propaganda, demonstrating that "Mussolini is one of us", the basis of the undisputed consensus on which Fascism built its politic.

The inhabitants' relationship with politics was also more intense in the Pontine Plain than in the colony: it was mandatory that everybody attend Sabato Fascista, or Fascist Saturday, held weekly in the main square, and many collective memories relate to marching and singing and communal gymnastic exercises.

\footnotetext{
${ }^{12}$ Memory is not always reliable, but it is interesting to note that none of the interviewees remember regular political meetings being held.

${ }_{13}$ Acquilina was born in 1931 and was eight years old at the time. In her stories, she often overlaps her own memories with those reported by her parents.
} 
Elvira reports that: "Not me, but my mum used to tell me about how, before she was married, they would leave home every Saturday and go to the square to take part in the feast. She wore her uniform of black skirt and jacket." [E.S.] ${ }^{14}$

And Maria to my question: "Did you ever see Mussolini?"

He was always in Latina!

Did you parade?

Always in the square, in black skirt and white shirt, and a pin with the symbol of Fascism here. Also in the rain. It was only propaganda. To make the square more lively! [M.A.] $]^{15}$

Cinemas were fundamental in the spread of messages of propaganda, and there were cinemas in many Libyan settlements.

Nereide, born in 1930, moved with her family from Veneto to Libya (Marconi settlement in Tripolitania) in 1938. In Marconi, there was a big cinema building, but Nereide remembers that it was used as a grocery shop, while all the cinema projections took place outside in the main square. The film would be announced by a kind of latter day town crier.

Vittorio recounts that in Bianchi, Tripolitania, films were shown once a week, and everybody from Giordani would take a bus to get there. The films shown were mainly Luce documentaries about Mussolini and the empire.

At that time, also in Italy, a short chronicle of the war was shown before the film. And no film started without a short Luce documentary showing Mussolini in person. They showed the empire and when they conquered Eritrea. ${ }^{16}$ [A.d.M.]

In the Pontine Plain, the Luce Institute documented step by step the building of the cities, as well as progress in the agrarian sector, the inauguration of public buildings, and visits paid by Mussolini, but none of the interviewees made reference to any public showings of any documentaries or movies.

On the other hand, on the subject of architecture, the cinema theatres were essential elements in the urban planning of the new towns: in Pontinia the cinema theatre is housed in one of the buildings which give shape to the square, in front of the municipality.

It seems that, while the propaganda machine was quite active, with a fully operational Fascist administrative apparatus in the Pontine Plain, it had no need of an extra layer of indoctrination through cinematic projections, while on the periphery of the

\footnotetext{
14 "Io no, invece mia mamma mi diceva che tutti i Sabati dal podere dove abitava, ancora non era sposata, veniva in piazza perché c'era la festa. Veniva con la divisa, con la gonna nera e con la giacca. Tutti i sabati venivano." [E.S.]

${ }^{15}$ Lo avete visto Mussolini? "lii! Stava sempre a Latina!" Vi facevano sfilare? "Sempre in piazza, gonna nera e camicetta bianca, e lo stemma del fascismo qua. Anche sotto la pioggia. Era tutto propaganda. Per rendere più vivace la piazza!" [M.A.]

16 "All'epoca anche in Italia prima del film c'era il film luce, cronaca illustrata degli avvenimenti bellici. E non c'era un film che iniziava dall'argomento. C'era sempre prima il film luce e durante il fascismo appariva Mussolini. Facevano vedere la conquista dell'impero, quando conquistato l'eritrea." [A.D.M.]
} 
empire, on the edge of the desert, films were the only medium to maintain the link between the inhabitants and the regime ${ }^{17}$.

\section{Conclusions: and nowadays?}

In Libya, after the vacuum left by the departure of the last Italian settlers, the colonial settlements were taken over by the local population. The reuse of both the dwellings and public spaces was characterised by pragmatic occupation (survey 2009): churches became sporting clubs or storage places, while schools continued to be used as schools; Individual farms continued to be used as living units ${ }^{18}$.

In the Pontine Plain many of the original houses can still be seen and are recognisable as houses on the landscape. The second and third generations of the original farmers live there, and many visual memories of that time still survive.

The presence of Fascism is still clearly observable today: in the urban nodes one can spot many political symbols, while, with the exception of a few cases, the public buildings continue to have the same function as they did during the Fascist era ${ }^{19}$.

The narratives about past political use of spaces are a precious source of information to help better understand the forms, hierarchies, design and reasons for what we see today. In this sense, talking about memories related to past political use of spaces is also a way to critically contextualise and historicise Fascism ${ }^{20}$.

\section{Acknowledgements}

MODSCAPES is a collaborative research project funded under the HERA - Humanities in the European Research Area 3rd Joint Research Programme dedicated to "Uses of the Past" (20162019). This project has received funding from the European Union's Horizon 2020 research and innovation programme under grant agreement $n^{\circ} 649307$

\section{Short resume}

Vittoria Capresi has been senior researcher at the Habitat Unit at the TU of Berlin since October 2016, as a PI of the International European Project MODSCAPES. Vittoria studied architecture at the University in Florence and at TU in Berlin, before moving to Vienna as a Teaching Assistant at the TU Vienna's department of History of Architecture (2002-2011). There, she was awarded her $\mathrm{PhD}$, which was published in 2010: The built Utopia. The Italian Rural Centres founded in Colonial Libya 1934-1940. Bologna, BUP. From 2011-2014 she was Associate Professor in History of Architecture and Urban Design at the German University in Cairo-GUC.

\footnotetext{
${ }^{17}$ Up until now it is unclear whether the intensity of the presence of politics at that time is echoed in the settlers' discourses on propaganda and politics. More research needs to be done on this.

${ }^{18}$ For more on pragmatic continuity in the use of the buildings in Libya see [11].

${ }^{19}$ Except for the Casa del Fascio and a few other typologies strictly related to the regime, functional buildings in Pontinia are still used as such: the police station, the municipality, the school etc. still maintain the same function as during the regime.

${ }^{20}$ More research on the perception of politics in the single dwelling and on the modernity of the planning is ongoing.
} 


\section{References}

1. PACHERA, L., 2010. Allontanati dalla nostra vita, Rovereto, Osiride.

2. PENNACCHI, A. 2008. Fascio e martello: viaggio per le città del duce. GFL Editori Laterza, Rome-Bari.

3. SEGRE, C.G., 1974. Fourth shore: the Italian colonization of Libya, Chicago, University of Chicago Press.

4. LABANCA, N., 2002. Oltremare: storia dell'espansione coloniale italiana, Bologna, II mulino

5. CAPRESI, V., 2009. L'utopia costruita: $i$ centri rurali di fondazione in Libia (19341940) = The built utopia: the Italian rural centres founded in colonial Libya (19341940), Bologna, Bononia University Press.

6. CULOTTA, P., GRESLERI, Giuliano, GRESLERI, Glauco, Barbera, P., 2007. Città di fondazione e plantatio ecclesiae, Bologna, Compositori.

7. MARTONE, M., 2012. Segni e disegni dell'Agro Pontino: architettura, città, territorio, Roma, Aracne.

8. SPIEGEL, D., 2010. Die città nuove des agro pontino im Rahmen der faschistischen Staatsarchitektur, Petersberg, Michael Imhof Verlag.

9. MASSARETTI, P.G., 2008. "The Spectacle of the 'Twenty Thousand'. The tragic Epic of Italian Colonialism in the Demographic Colonisation Villages of Libya", in E. Godoli, B. Gravagnuolo, G. Gresleri, et al. (eds.), The Presence of Italian Architects in Mediterranean Countries: Proceedings of the First International Conference, (Bibliotheca Alexandrina, Chatby, Alexandria, $15^{\text {th }}-16^{\text {th }}$ November 2007), Florence, Maschietto: 52-65.

10. CONTE, N., CECCONI, B., 2003. Racconti della Memoria. L'identitá culturale del territorio di Pontinia ieri e oggi, Pontinia, Felici \& Gagliardi.

11. CAPRESI, V., 2012. "Eredità e permanenze del colonialismo italiano in Libia. Continuità negli interventi urbani / architettura / simbolo", in F. Pouillon, N. Amara, C. Jelidi, V. Capresi (eds.), De la colonie à l'Etat-nation: constructions identitaires au Maghreb, Thèmes, Études, Chroniques et opinions, (Maghreb et sciences sociales: 2012), Paris, IRMC-L'Harmattan: 207-219. 